\title{
Leo Lowenthal's Critical Theory of Populism and the Crisis of Liberal Democracy
}

\author{
Lars Rensmann \\ Director of the Centre for the Study of Democratic \\ Cultures and Politics \\ Professor of European Politics and Society \\ University of Groningen \\ l.p.rensmann@,rug.nl
}

\author{
Faculty of Arts \\ University of Groningen \\ Oude Kijk in 't Jatstraat 26 \\ 9712 EK Groningen \\ The Netherlands
}

(C) Lars Rensmann; do not cite without author's permission 


\title{
Leo Lowenthal's Critical Theory of Populism and the Crisis of Liberal Democracy
}

\author{
Lars Rensmann (University of Groningen)
}

\begin{abstract}
This paper focuses on the Frankfurt School's critical theorist Leo Lowenthal (1900-1993) and the contemporary relevance of his theory-guided social research on authoritarian politics. Grounded in a close reading of his work, the essay reconstructs Lowenthal's theoretical interpretations and empirical studies. Illuminating three critical paths paved by Lowenthal for studying the rise of authoritarian-populist demagoguery within modern democracies - political-psychological, economic, and socio-theoretical - the paper discusses in how far his critical-theoretical research can serve as a resource for theorizing current populist agitators' appeal in America and Europe today. In so doing, the paper brings classical findings of the Frankfurt School into dialogue with recent political science studies and political theory on resurgent authoritarian populism and related crises of liberal capitalist democracy. Lowenthal's critical theorizing may complement current explanations for the populist surge in context of a new age of post-factual politics in a profoundly transformed public sphere.
\end{abstract}

Keywords: critical theory, democracy, Frankfurt School, Lowenthal, populism

\section{Introduction: Leo Lowenthal's Social Research Revisited}

In light of the rise of populist actors around the globe, the Frankfurt School's multilayered political analysis and theorizing of authoritarian agitators has lately found renewed interest within political theory and political science. However, the long forgotten work of the German-American political sociologist and émigré Leo Lowenthal, one of the founding fathers of the 'inner circle' of the Frankfurt School's Critical Theory, has still mostly been overlooked in current scholarship. In the still proliferating studies of the Frankfurt School's scholarly work and theoretical impact, Leo Lowenthal, one of the School's 'founding fathers', is mostly treated as a marginal figure. ${ }^{1}$ This also applies to the recently revived interest in the

\footnotetext{
${ }^{1}$ See Peter-Erwin Jansen, "Leo Lowenthal: Ein optimistischer Pessimist," Zeitschrift für kritische Theorie 8 (2002), pp. 7 - 40. Most of these conceptions are usually identified with the names of Theodor W. Adorno and Max Horkheimer. While Herbert Marcuse's work strongly resonated in America during the roaring sixties, symbolizing the outright political wing of the Frankfurt School and making him a theoretical hero of the student movement, in most cases
} 
Frankfurt School's social research on authoritarianism and social resentment, although Lowenthal played a crucial role in developing ground-breaking theoretical conceptions, research designs, and experimental methods understanding and exploring authoritarianism as a key problem of modern society, politics and culture. Most importantly, Lowenthal made some distinct, yet still overlooked contributions to the study of authoritarian politics and culture within modern democracies.

It is argued here that his work is worth revisiting in the face of the current global resurgence of democratically elected forms of authoritarian populism, from the Trump phenomenon to right-wing populist movement-parties in European parliaments and governments and new populist actors in many other countries: authoritarian populists who do not just challenge specific policies of established parties and previous governments but also the very condition of possibility of democracy as an egalitarian and emancipatory idea and practice. Lowenthal's social research and critical theorizing offer distinct insights into the societal origins of authoritarianism, as well as the dynamics, devices and appeal of modern authoritarian politics. In so doing, his work may also provide critical resources to understand the current anti-liberal, authoritarian-nationalist revolt from below and above, and the attraction of ,post-factual democracy' — which undermines the very conditions of democracy_in an age of increasingly post-liberal, globalized post-industrial capitalist societies.

The article proceeds in three steps. First, Lowenthal's analysis of a decentral authoritarian demand and its conditions in modern capitalist democracies — his social theory of authoritanism as developed mostly in Germany before his American exile--is briefly reconstructed. It is situated within the context of the Frankfurt School's theory-guided

Leo Lowenthal (who stayed in the U.S., like Marcuse, but different from Adorno and Horkheimer) is merely mentioned as the fourth member of the Institute's so-called 'inner circle'. His contributions remain largely unnoticed by contemporary social theorists and social scientists. Political theorist Seyla Benhabib, for instance, does not discuss a single one of Lowenthal's studies in her brilliant systematic study of critical theory, neither does Craig Calhoun in his influential work on contemporary critical social theory; here, too, Lowenthal only appears as an additional name to be remembered; see, as one instantiation of many others, Craig Calhoun, Critical Social Theory (Oxford: Blackwell, 1995), p. 14. 
research and Lowenthal' contributions to this research agenda. I hereby analyze Lowenthal's understanding of modern authoritarianism in a re-adjusted critical theory of society after the Holocaust, but also point to its historical limitations. Second, Lowenthal's qualitative analyses of authoritarian political mobilizations are reconstructed. They are the product of theoryguided experimental and analytical empirical work produced in the US, and based on American agitators and workers. The section especially focuses on his empirical study Prophets of Deceit (1949). This work examines American radical rightist demagogues in the 1940s, the political agitation techniques they employ and, most importantly, the sociopsychological origins, effects, and meaning of their appeal. Third and finally, the possibilities (and limits) of Lowenthal's interpretative social research will be briefly discussed from a contemporary perspective, and particularly in light of the current global 'authoritarian revolt.' It is argued here that Lowenthal's critical-theoretical work offers altogether three interrelated insights and directions for theory-guided research on authoritarian populism within democracies today, namely in the areas of political psychology, critical political economy, and social theory. The ultimate goal is to initiate a critical dialogue between Lowenthal's insights and recent social research on the rise of authoritarian politics within democracies, and thus to prepare the ground for a contemporary critical theory of authoritarian populism.

\section{Theorizing Authoritarianism: Lowenthal and the Critical Foundations of a Concept}

Lowenthal's oeuvre is multi-faceted and multi-disciplinary, reaching from studies in the sociology of literature to work on the production, communication and reception of popular culture in modern societies. For Lowenthal, it is argued here, the concept and theory of authoritarianism hereby almost thoroughly serves as an analytical leitmotif in all of his work, at least since the 1930s. Prompted by the Frankfurt Institute for Social Research's prescient perception of authoritarian potentials in the prelude to fascism - and eventually by the fact that Nazi terror was possible in the midst of modern civilization - the concept continued to 
play a key role even in those of Lowenthal's sociological endeavours that prima facie seem to deal with other issues entirely. These range from his famous essay on the underlying “authoritarian ideology" in Knut Hamsun's literature to the empirical study of standardized popular biographies. According to Lowenthal, the latter display the hollow image of individual strength or individualism. This image carryies ideological functions in an increasingly economically post-liberal society, largely dominated already in the first decades of the twentieth century by large monopolistic corporations, in which the very conditions of individuality are continuously undermined. Hamsun, Lowenthal suggests, confronts the readers with their own social impotence while glorifying the individuality of popular heroes. His sociological interpretation of Knut Hamsun's widely admired literature had originally exposed the authoritarian disposition to fascism in Hamsun's work. ${ }^{2}$ Lowenthal discovers "authoritarian modes and themes that had long been implicit in his novels: the pagan awe of unlimited and unintelligible forces of nature, the mystique of blood and race, hatred of the working class and of clerks, the blind submission to authority, the abrogation of individual responsibility, anti-intellectualism, and spiteful distrust of urban middle-class life."” Lowenthal sees a conformist mythology of "necessary sacrifice to a natural process" at play that serves as a guiding, integrative principle in Hamsun's books. They affirm that "people should accept life as it is, and that means the existing relations of domination and subordination, of command and serve." ${ }^{4}$ Thus, the theoretical motif of authoritarianism helps to conceptionalize Lowenthal's work and overall intentions_-just as Lowenthal's innovative empirical contributions to the study of authoritarianism in culture and politics may offer critical tools for its study in the presence. This includes the global authoritarian populist revolt currently unsettling liberal democracies.

\footnotetext{
2 Exclusively by analyzing Hamsun's literature, Lowenthal predicted Hamsun's later political affiliation and support for the Nazi regime, which took most intellectuals at the time by surprise.

3 Leo Lowenthal, "Chapter VII: Knut Hamsun (1860 - 1952)," in Lowenthal, Literature and the Image of Man: Sociological Studies of the European Drama and Novel, 1600 - 1900 (New York: Boston: Beacon Press, 1970), pp.190-220, here p. 190.

${ }^{4}$ Ibid, p.218.
} 
This first section focuses on Lowenthal's social theory of authoritarianism, which was mostly developed in context of the Frankfurt School in the German political-geographical until the escape to the US in the 1930s. To explore the dynamics of modern authoritarianism, antisemitism, and social resentments was, to be sure, also a central objective of most of the Institute's collaborative projects in the 1940s. This objective was, of course, less of a voluntary choice bur forced upon them in the context of their time and their own struggle for survival as persecuted Jews: a reflection of the rise of European fascism and Nazi totalitarianism at the time, of the Institute members' forced exile, and partly the concrete need to acquire financial resources by means of empirical research. ${ }^{5}$ Starting from a Marxist framework, the critical theorists in the formative early exile period addressed the question why social masses internalized repressive social orders and followed authoritarian and antisemitic demagoguery, instead of breaking with class oppression or advancing progressive causes. The initial question driving the Frankfurt School's research in view of the rise and support of new fascist authoritarian regimes was why, as the theorists phrased it, citizens tended to act against their own "objective" class interests (from early on, for the Frankfurt School scholars this implied that they acted against both their collective and particular individual human interests). Coercion and physical compulsion could not be sufficient explanations, especially in the initial stages of fascist rule, as large parts of European populations had voluntarily voted for Nazi and fascist leaders; this includes the last democratic elections in the Weimar Republic in 1932.

In response to totalitarian fascism and the Nazi crimes against humanity— the Frankfurt School scholars recognized the Holocaust as the 'central injustice' of their timeCritical Theory itself transformed into a unique, independent post-Marxist school advancing a distinctly new historical materialism. It intended to understand the "eclipse of reason" in the

\footnotetext{
${ }^{5}$ Lars Rensmann, The Politics of Unreason (Albany, NY: State University of New York Press, 2017), chapter 1.
} 
midst of modern civilization. ${ }^{6}$ Over two decades the Critical Theorists developed a new, socio-theoretically and socio-psychologically grounded understanding of (the nature and scope of) authoritarianism and authoritarian rebellions within and against modern civilization.

Given the global scope of the phenomenon, the Critical Theorists suggest that the rising popularity of authoritarians in the $20^{\text {th }}$ century points to universal trends: they could not be explained by particular national contexts alone but had to also be placed in the context of structural transformations of social integration, and modern society at large. They began analyzing authoritarianism as a product of the universally objectifying conditions of the sociocultural system of administered capitalism and political modernity that reinforced certain dispositions on the level of individual subjectivation and had specific effects on the innermost aspects of the human psyche. These conditions, they argued, structurally engendered—and made citizens susceptible to-submission, collectivist conformist orientations, and authoritarian aggressions against "others" on almost every level of social life. While no political tendency is considered inevitable, these conditions are viewed as favorable for the authoritarian political mobilization of social paranoia and anti-civilizational revolts with the aim to unleash social violence, to 'break out' of civil society, and to break with established authority structures perceived as 'weak' - including the democratic state and its actual or imagined representatives.

In Lowenthal's view, the problem could thus not be understood without the sociopsychological processing of the transitions and (dis-)integration processes of modern society: the very society that represented the promise of freedom and democratic mass participation but, Lowenthal argues, largely failed to deliver on its promises, thus involuntarily betraying them as 'inauthentic' and false. The material deadly social force of fascist or authoritarian revolts - and the powerful appeal of the authoritarian and antisemitic ideologies guiding

\footnotetext{
${ }^{6}$ Rensmann, The Politics of Unreason, p.236.
} 
them - would have, then, also a significant meaning for our understanding of modern society as a whole.

In the early, in many ways pathbreaking essay on Authority in bourgeouis society, Lowenthal had laid out an initial basis for his — and the Frankfurt School's — understanding of the pressing issue of authoritarianism in modern society. ${ }^{7}$ The essay is rooted in Lowenthal's previous and parallel work on a critical sociology of literature that explored bourgeois socialization and acculturation configurations across the centuries. ${ }^{8}$ This allowed him to discern the historical traces of most patterns of authoritarian submission examined in the rest of the Studien, ${ }^{9}$ incorporating a whole range of diverse philosophical, historical and psychological references. ${ }^{10}$ Although the essay is partly framed by a pre-Holocaust, conventionally Marxist, indeed rather economistic approach and class theory, it provides a first innovative incorporation of Freudian psychological theory into a politico-cultural analysis of the problem of authority in the course of history — and into its changing, supposedly increasingly irrational character in modern society. Lowenthal contextualizes the dynamics of authority and authoritarianism, that is: the irrational or blind submission to political and social authorities or structures, in different historical periods and societal structures. He examines the continuities and transformations of authority in what he calls the “cultural system." It embodies "all organizations and structures, such as governmental and legal institutions, the educational system, and the psychic makeup of the individual" 11 that

\footnotetext{
7 This essay from 1934 was first published in 1982, almost fifty years after it had been written; see Leo Lowenthal, "Toward a Psychology of Authoritarianism," in Lowenthal, False Prophets: Studies on Authoritarianism. Communication in Society, Vol.3 (New Brunswick, NJ: Transaction, 1987), pp.255-297. See also the German original: Leo Lowenthal, "Autorität in der bürgerlichen Gesellschaft," in Lowenthal, Falsche Propheten: Studien zum Autoritarismus. Gesammelte Schriften Bd.3 (Frankfurt a.M.: Suhrkamp, 1982).

${ }^{8}$ While Herbert Marcuse added a third theoretical essay to the Studien that focused on ideological concepts of authority in the history of ideas, this fourth, general essay on authoritarianism in bourgeois and modern society, written by Lowenthal in 1934 (one year after the Nazis seized power), was not published in the volume but was originally planned to become a part of it.

${ }^{9}$ See Martin Jay, The Dialectical Imagination, p.135.

${ }^{10}$ Helmut Dubiel, „Editorische Nachbemerkung, “ in Lowenthal, Falsche Propheten, p.336.

${ }^{11}$ Leo Lowenthal, "Toward a Psychology of Authoritarianism," p.255.
} 
transcend the realm of immediate physical compulsion and the economic material basis. ${ }^{12}$ For Lowenthal, this institutional and psychological "totality of culture" has different functions that stabilize an existing social order, whereby authority and power relations, psychology, and culture as a whole are seen as strongly linked to economic processes: in "all social orders to date," Lowenthal argues, "relations of production were at the same time interspersed with relations of authority, and the latter were molded by the former."13 Even the historical differences between liberal and totalitarian forms of authority and power, Lowenthal believes, "often reflect the economic situation"14 (though, like Max Horkheimer, Lowenthal admitted that there is a "cultural lag" that might be resilient even when the original socio-economic cause has disappeared).

In a rather Marxist-functionalist manner, Lowenthal hereby assumes that authoritarian behaviour also functions in the interest of the ruling minorities' desire to preserve the status quo. ${ }^{15}$ In modern society, authoritarian relations are, in this view, to a relevant extrent related to the necessities of the capitalist mode and its veiled authoritarian organization of production: capitalist class relations allegedly affect authoritarian relations in all spheres of modern society, though there is also a reciprocal interaction between them. ${ }^{16}$ Thereby power, the indispensable ingredient of authority, Lowenthal points out, is dependent on voluntary submission: on a culturally induced, internalized psychological affinity towards obedience. ${ }^{17}$

While Lowenthal sees an intrinsic conformism due to the demands of capitalism, assuming that "feelings themselves already undergo a process of formation by existing social relations along the lines of a predisposition for authoritarian relationships," Lowenthal also recognizes the contradictory, two-fold nature of the modern social consciousness of authority:

\footnotetext{
${ }^{12}$ In Marxist terms, Lowenthal's notion of culture largely translates into the "superstructure".

13 Ibid, p.265.

14 Ibid, p.267.

15 See ibid, p.274.

16 The following optimistic prediction is also very much indebted to a Marxist philosophy of history: Lowenthal believed that 'eventually', in the new totalitarian states, "although authoritarian institutions may very well deteriorate into sheer physical oppression, and finally into terror, this very process generates the tendencies for the totalitarian system's final collapse." See ibid, p.269.

17 See ibid, p.271.
} 
new forms of an 'abstract authority' would go along with a simultaneous struggle against authoritarian thinking in the formation of bourgeois society and modern science. ${ }^{18}$ The antiauthoritarian program of the bourgeoisie, says Lowenthal, contains liberal-egalitarian legal principles and the right to unlimited individualistic action. However, this political program leaves socio-economic authority structures unchallenged and becomes increasingly out of sync with the monopolistic accumulation of power and wealth to which unregulated capitalism tends. In bourgeois society, the conscious authoritarian reverence of the absolutist state power is replaced by the authoritative pretensions of private property and the market economy, which leads to its self-destruction and ever increasing, unchallenged concentrations of power and resources. ${ }^{19}$ Yet these abstract and allegedly 'rational' forms of power and authority, grounded in property and market power, form an entirely new, hidden and invisible as much as seemingly inescapable, reified and abstract relationship of authority and domination, which pays the way for a backlash into direct, brute authoritarian force.

In his examination of the French Revolution, Lowenthal already finds the problems of the new model of modern authoritarianism encapsulated. For the first time, the revolution allegedly displayed the internalized sado-masochistic nature of the (petty-)bourgeois individual in full force. Its character type is marked by a Protestant ethic of austerity, asceticism, and envy as much as by indifference and coldness towards other individuals. For Lowenthal, this psychological profile correlates with new, abstract forms of authority and universal dependency ingrained into the capitalist system, which appears natural and inevitable. The French Revolution

"unleashed the principles of a petty-bourgeois morality: absolute severity toward powerlessness while simultaneously respecting power and the cruelty of the thrifty and 'respectable' individual. In the battle with his own drives, this individual becomes sadistic and begins to envy those who - in fact or only apparently - are capable of pleasure (bourgeois resentment of the nobility and anti-Semitism have similar psychological origins). The belief that one must conform to exisiting conditions and that blind necessity knows no other considerations is what led to the idea of the guillotine. The guillotine symbolized total

\footnotetext{
18 See ibid, p.262.

19 See ibid, p.279.
} 
indifference to individual fate and values, and corresponded to the system that the pettybourgeois masses of the cities had already embraced and that had, through their efforts, won general power. In this system, societal necessity was carried out blindly and without respectnot, however, without authority." 20

In Lowenthal's view, this new system of universal dependency generated by the anonymous powers of the market — the objectifying indifference of the capitalist reproduction--(re-)produces the sado-masochistic, authoritarian desires related to a feeling of hopeless dependence. It also reifies "the conviction that oppression is objectively necessary and that if one cannot avoid it oneself, then others should also be subjected to it; the idea of a natural process as the model of human society" and the corresponding specific "bourgeois trust in authority, bound to the feelings of spite and egoism, experiences satisfaction at the sight of the suffering of others." ${ }^{21}$ This is Lowenthal's original attempt to link the dominant, modern capitalist rationality, as well as the abstract authority principles and universal structural dependency it generates, with new psychological dispositions to internalized conformist submission and authoritarian-aggressive desires.

These specific dispositions, Lowenthal notes, are not primarily due to conscious propaganda or physical threats, but to a psychological anchoring and reinforcement of authoritarian behaviour. He attributes hereby a major role to the bourgeois nuclear family with its quotidian modes of domination and subordination. The family itself is authoritarian both in its own structure and in what it teaches: the internalization of discipline and subordination and the "proper perspective of reality." Like Horkheimer, Lowenthal suggests that in bourgeois society, authority of the father derives directly from the man's role in production. He possesses this authoritarian position of dominance in the family by virtue of his economic function and supremacy. ${ }^{22}$ Internally, thus, authority has a rational foundation. In contrast to Horkheimer, Lowenthal, however, does not yet see a profound structural change

\footnotetext{
${ }^{20}$ Ibid, p.282f.

${ }^{21}$ Ibid, p.283.

22 Ibid, p.287f.
} 
of this family structure. The "fundamental form" of the family, he claims, "remains unchanged" 23 in the modern era. But he also recognizes that this paternal authority turns fully irrational in times of large-scale economic crises: when the father loses his "leading function in the economy or sank into unemployment and poverty, then this negative phenomenon shows that the positive subordination to paternal authority - characteristic for the bourgeois family in earlier epochs - stands in direct relation to the father's actual position," and thus authority becomes irrational in itself. Moreover, with the rise of society's direct influence, secondary institutions come to determine the socialization process and exercise direct control and power over the individual. In the end, authoritarianism becomes synonymous with the acceptance of, and blind identification with, the social order itself. At any rate, though still embedded in a rather conventional Marxist understanding, this initial essay provides important insights into the relationship between capitalist society and authoritarianism.

The more 'traditional' Freudian-Marxian model initially employed in the 1930s was modified, specified and expanded in the course of Lowenthal's theoretical development, and that of Critical Theory at large, in the 1940s. ${ }^{24}$ Three central theses signify Lowenthal's and the Frankfurt School's re-adjusted, advanced critical social theory of modern authoritarianism. They point to the general shifts in Critical Theory's perspectives on society, especially their further reconceptualization - or departure from - Marxist theory, and their reframing of the concept of culture and the social question in the context of 'modernity'.

First, Marx's and Lukács' theory of reification turned into a central paradigm. Signifying an "objective consciousness form" than turns the entire living object world into exchangeable goods of abstract value, reification was perceived to be constitutive for all social relations and forms of consciousness in the social totality of the modern era. As modern capitalism utilizes and reifies everything and turned it into abstract value, so were all social relations marked by an increasing reduction to a mere instrumental, objectifying rationality,

\footnotetext{
23 Ibid, p.286.

${ }^{24}$ See Martin Jay, Force Fields: Between Intellectual History and Cultural Critique (New York: Routledge, 1993), p.20.
} 
which totalizes tendencies inherent in the bourgeois logic. This universalization of a specific trype of rationality undermines individual freedom and aims at the strict domination and exploitation of the object-world for unreflected self-preservation purposes, while the process itself atomizes the subjects. ${ }^{25}$ As Lowenthal argues in Terror's Atomization of Man, though, a free society may still be possible, if mankind could only free itself from the "use of human beings as surplus or commodities or means." ${ }^{26}$ Going along with this reification paradigm, viewed as a product of a new totality of social entanglement in an commodified and "administrated world" of late capitalism, was the assumption that individuals suffered from a "loss of experience" blimdly detaching them from living objects: inner, external, and human. The effects of this process would be a stereotypical "ticket mentality" that only allowed a conformist, standardized view of the world. This, of course, was seen as a typical feature and origin - of modern authoritarianism.

The underlying new, specific distinctions between an early bourgeois and a modern period were also apparent in a second major claim, namely that this stereotypying, loss of experience and authoritarianism was reinforced by a new culture industry that came into being in the $20^{\text {th }}$ century. The commodification of social world also entailed the sphere of cultural reproduction. According to Critical Theory, mass culture has further locked the individual imagination and capabilities to experience into a standardized system of consciousness while socially expropriating even the most intimate emotional structures. Like instrumental rationality in general, it fosters the homogenization and exclusion of difference, ${ }^{27}$ as Lowenthal demonstrates in studies of new cultural products and media reception, such as his radio research on The Triumph of Mass Idols (1944) and The Biographical Fashion (1955). ${ }^{28}$

\footnotetext{
25 Axel Honneth has described this mode of action as the mode of labor; see Honneth, The Critique of Power.

${ }^{26}$ Leo Lowenthal, "Terror's Dehumanizing Effects," in Lowenthal, False Prophets, p.179 - 191, here p.190.

27 On this aspect, see most recently Morton Schoolman, Reason and Horror: Critical Theory, Democracy, and Aesthetic Individuality (New York: Routledge, 2001), pp.79ff.

${ }^{28}$ See Leo Lowenthal, Literature and Mass Culture. Communications in Society, Vol.1 (New Brunswick: Transaction, 1984).
} 
Finally, Lowenthal further re-adjusted the thesis of a weakening ego beyond the patterns of bourgeois society. Authoritarian character dispositions and the decline of individual self-regulation competences are largely seen as a product of multiple, if not universal dependencies in modern society, the weakening of the family as an agency for individualization, and direct social pressures of advanced capitalism affecting all aspects of human life. This theory of modern authoritarianism also offers new distinctions: the relative autonomy within early bourgeois society, provided at least to some of its more privileged members, stands in contrast to the modern "subject without subjectivity", a direct, no longer mediated effect of social mechanisms and their institutionalization. The authoritarian personality, then, was to become a new historical form of subjectivity in modern society, emblematic of the 'modern condition' as a whole (though the empirical study on The Authoritarian Personality also contrasted the liberal personality to the authoritarian one). According to the Critical Theorists, this , authoritarian personality ${ }^{6}$ can be viewed as the ideal type, in a Weberian sense, of modern personality structures.

These core hypotheses were influenced by, and to a large extent correlate with, the scholars' empirical research of the 1940s, which focused on the micro-dynamics of authoritarian psychic dispositions and political propaganda. Placing the Freudian psychoanalytical model in the social context of modernity, the critical theorists continued to assume that the authoritarian character's ego results primarily from modern socialization processes. On the micro-sociological and psychological level of the Frankfurt School's advanced authoritarianism theory, the authoritarian mentality is portrayed as fundamentally weakened, decomposed, and disintegrated in relation to his other psychological instances, which are out of balance, but largely integrated into modern society. ${ }^{29}$ Hatred towards those

\footnotetext{
${ }^{29}$ The major hypothesis of The Authoritarian Personality is that "the political, economic and social convictions of an individual often form a broad and coherent pattern, as if bound together by a 'mentality' or 'spirit', and that this pattern is an expression of deeplying trends in his personality", potentially fascist individual "whose structure is such as to render him particularly susceptible to anti-democratic propaganda." Adorno et. al., The Autoritarian Personality, p.1.
} 
seen as weak and those who enjoy pleasure but obedience to the strong and morally rigid; authoritarian aggression and conformist submission, in particular to power and rigid norms of order; and a stereotypical mentality that is as much susceptible to binary worldviews and prejudices as it is to collectively narcissistic gratifications that relieve and satisfy the weakened ego: these are the main features of the authoritarian personality syndrome according to Lowenthal and Critical Theory. ${ }^{30}$

And this authoritarian character is not external to, or outside from, modern capitalist, nationally circumscribed democracies. Rather, it is reproduced within democratic societies from which authoritarians want to break out, due to underlying conditions and contradictions that undermine democracy's emancipatory potential. In Lowenthal's view, then, modern society's enormous pressures to conform to social norms and economic demands, which fundamentally restraint the freedom of the individual, reinforce universal dependencies that profoundly harm individual cognitive and moral competences — and make individuals susceptible to arbitrary forms of antidemocratic or ethnocentric political propaganda, cultural imaginaries glorifying power and brute force, and collective regressions. Especially modern antisemitism could hereby projectively mirror and satisfy the authoritarian needs for orientation by providing an all explanatory reality principle in form of a structurally "paranoid relationship to the outside world" 31 . Here the active mobilization of authoritarian politics, agitation and devices, comes into play, which reinforces, ideologizes and unleashes sociopsychological dispositions.

\section{III. "Psychoanalysis in Reverse": Lowenthal's Research on Authoritarian Politics}

The empirical application and theoretical confinement in light of empirical studies evolved in the US, after Lowenthal's escape from Germany. Translating his social theory of

\footnotetext{
30 See Adorno, The Authoritarian Personality, pp.151-191.

${ }^{31}$ Lowenthal, Prophets of Deceit, p.32.
} 
authoritarianism into an analysis of political actors mobilizing authoritarian demand, Lowenthal's studies of authoritarian 'demagogues within democracy' decipher the main techniques, civil transgressions, and underlying politico-psychological dynamics shapingpartly effective - specific right-wing propaganda in America at the time. In Prophets of Deceit: A Study of the Techniques of the American Agitator (1949) ${ }^{32}$, Lowenthal employs a unique, psychologically informed content analysis of American fascist speeches that 'deconstructs' their political communication strategies and the causes of their effectiveness in an immediate and broader sense. The empirical research findings on "images of prejudice" previously drawn from interviews with American workers (as part of his study of AntiSemitism among American Labor, 1944-1945) hereby underscore the social susceptibility to psychological and stereotypical dynamics which right-wing authoritarianism could utilize.

The underlying general thesis of Lowenthal's analysis of political agitators, which is based upon a thorough study of speeches by several radical right demagogues of the time, is rooted in his social theory of modern authoritarianism: the political agitator could exploit "the stresses imposed on the individual by he profound transformations taking place in our economic and social structure-the replacement of the class of small independent producers by gigantic industrial bureaucracies, the decay of the patriarchal family, the breakdown of primary personal ties between individuals in an increasingly mechanized world, the compartementalization and atomization of group life, and the substitution of mass culture for traditional patterns." 33 In other words, authoritarian political ideologies and propaganda devices coud count on, and potentially mobilize or reinforce, wide-spread socio-psychological authoritarian dispositions in a contradictory, profoundly unjust and precarious modern society. What people experience as a social malaise, Lowenthal argues, is "a consequence of the depersonalization and permanent insecurity of modern life." ${ }^{34}$ It is allegedly "basic to

\footnotetext{
32 First results appeared in The Public Opinion Quarterly (1948).

${ }^{33}$ Lowenthal, Prophets of Deceit, p.25.

34 Ibid, p.27.
} 
modern society. Distrust, dependence, exclusion, anxiety, and disillusionment blend together to form a fundamental condition of modern life: malaise." Although it actually reflects social reality, it "also veils and distorts it. Malaise is neither an illusion of the audience nor a mere imposition by the agitator; it is a psychological symptom of an oppressive situation" which is affirmed and simultaneously utilized by anti-democratic agitation. For Lowenthal, the agitator is a specific "advocate of social change" who simultaneously affirms existing social relations. He increases the members' disorientation by destroying all remaining rational guideposts without addressing policies or structures generating injustices, atomization, and exclusion. ${ }^{35}$

While anti-democratic agitation aggravates, affirms and fixates an "oppressive situation", however, it also reflects the societal malaise that is experienced as an internal psychic condition in its own characteristic features: its diffuseness, its pseudospontaneity, its flexibility in utilizing a variety of grievances, and its substitution of a personal enemy for an objective situation. ${ }^{36}$ Political agitation manipulates its audience. Yet it also mirrors the stereotypical perceptions which it amplifies. The agitator thereby absorbs the internal, authoritarian psychic conditions of the listeners. He plays upon psychological predispositions with psychological weapons. He is doing so in a kind of a "psychoanalysis in reverse" (Lowenthal) that obscures, rather than illuminates, the unconscious psychological problems of the listeners. ${ }^{37}$ The fascist agitator is not thoroughly irrational, despite of own authoritarian dispositions; rather, as Adorno once put it, he is a talented salesman of his own psychic defects.

Though informed by classical ideology critique that distinguishes between the illusion or deceit and 'objectivity', Lowenthal's empirical cultural and political studies only reluctantly employ Marxist theory and concepts, whereas Freud's influence is very obvious. ${ }^{38}$

\footnotetext{
35 Ibid, p.15.

${ }^{36}$ Ibid, p.24f.

${ }^{37}$ Lowenthal quoted in Jay, The Dialectical Imagination, p.173.

${ }^{38}$ Lowenthal and Guterman also introduced the work of Erik Erikson to supplement Freud's seminal insights; see Martin Jay, The Dialectical Imagination, p.105 and p.238.
} 
However, his studies do try to "unmask" the "objective" content of the phenomenon and its relevance as a latent trend in society as a whole. The problem of agitation "should be studied in the light of [its] potential effectiveness within the context of modern society and its dynamics, rather than in terms of [its] immediate effectiveness, ${ }^{39}$ Horkheimer argues in the preface. Lowenthal's approach to analyze the standardized products of political agitation or, later on, popular biographies avoided any straight-forward methodological standardization and thus, according to Adorno, "represents a very legitimate parody of the official practice of content analysis"40 that conventionally aims at the quantification of words and sentences within in texts: "Against the nonsense that is blossoming under the title 'content analysis', in which quantitative methods themselves proceed ad absurdum," writes Adorno, "it [Prophets of Deceit] is a highly effective antidote." ${ }^{41}$ Although both Adorno and Lowenthal took the problem of (American) fascist agitation seriously as a socio-political phenomenon rather than treating it as a "lunatic fringe", as Marcuse noted in his preface to the 1969 edition of Prophets of Deceit, both viewed authoritarian agitation as an extreme expression of culture industry's standardized products. ${ }^{42}$ Yet they also sought to disclose the specific ideological structures, techniques, and the political-psychological effects of this kind of agitation.

Exploring what is common in the various anti-democratic agitational material, Lowenthal finds a set of standardized devices and themes that consistently reoccur in radical

\footnotetext{
${ }^{39}$ Horkheimer, "Foreword," in Lowenthal, Prophets of Deceit, p.2.

40 Quoted in Leo Lowenthal, "Recollections of Theodor W. Adorno (1983),” op.cit., p.71.

${ }^{41}$ Adorno in Lowenthal, "The Correspondence of Leo Lowenthal with Theodor W. Adorno," p.142. Reading these comments and communications between Lowenthal and Adorno on this issue, one should reflect that Adorno was much more distant to empirical research applications than Lowenthal, although both shared a strong critique of what they perceived as 'positivistic', isolated empiricism and the indiscriminate application of quantitative methods to different subjects. Lowenthal, however, was more pragmatic and open-minded in his approach to empirical research. He proved to be less reluctant to the use of various empirical methods, which were sometimes sweepingly denounced by his fellow colleagues Adorno, Horkheimer and Marcuse. Lowenthal also kept a life-time friendship to Paul Lazarsfeld, with whom Adorno had heavy disputes about empirical standards of research, resulting in a split in spite of Lowenthal's attempt to mediate the conflict. Eventually, Lazarsfeld declined to integrate the Institute into Columbia University after War. See Peter-Erwin Jansen, "Leo Lowenthal: Ein optimistischer Pessimist," p. 32; Martin Jay, The Dialectical Imagination, p.115f.

42 See Martin Jay, The Dialectical Imagination, p.237.
} 
right-wing communication strategies. ${ }^{43}$ Although they are extracted primarily from American agitators, Lowenthal assumes that the general elements, themes and techniques are always the same even in varying political contexts. The analyst is "struck by the unmistakable similarity of their content and tone." The careful examination shows that this similarity "is not accidental but based on a unifying pattern." ${ }^{\prime 4}$ The psychological key mechanisms include personalization of social problems; projection of instincts; authoritarian identification; (collective) self-idealization; and ritualistic repetition. Most themes of the agitation are circling around resentments and fear. However, these themes, Lowenthal argues, cannot be understood in terms of their manifest content. They rather constitute a kind of secret psychological language. $^{45}$

Lowenthal conceptualizes 21 major themes and devices and many more sub-themes, of which many seem to resonate in today's right-wing populist narratives. It is, as Jack Jacobs observes, the "latent rather than the manifest meaning of the agitators' speeches that is of import — and the latent meaning is one that can be deciphered by use of psychoanalytic insights." (Jacobs, 2015: 98) The following themes and devices are most striking:

(1) According to Lowenthal, the agitator refers to his followers as common people, the great "little men", portraying himself as the genuine democrat who lends his voice to the "silent majority", in this case the "simple Americans". He thus appears as a "self-appointed popular spokesperson." ${ }^{46}$ With such allusions, he might seek to disavow the antidemocratic implications of his discriminatory statements, and to give his followers a sense of strength and participation. ${ }^{47}$ But this is also a device, Lowenthal suggests, "that by its very nature often tends to transform democratic psychological patterns into totalitarian ones. Closely related to the common resentment against anyone who dares to be different and hence implicitly

\footnotetext{
${ }^{43}$ Lowenthal's insight into the nature of political agitation could build on Adorno's earlier study and also benefitted from the parallel work on resentments and the susceptibility to demagoguery. Lowenthal influenced, in turn, Adorno's later writings on the subject.

${ }^{44}$ Lowenthal, Prophets of Deceit, p.14.

${ }^{45}$ See ibid, p.151.

46 Ibid, p.5.

47 See ibid, p. 120 .
} 
directed against minority groups, it establishes conformism as a good in itself." 48 In fact, with this authoritarian-conformist notion of political participation that provides only the "leader" with legitimacy, Carl Schmitt's notion of democracy is applied: the "democratic approval" to the agitator's vision should be achieved by (conformist) acclamation. Lowenthal calls this concept of "democracy" the "totalitarian plebiscite". ${ }^{49}$ In the end, the anti-democratic agitator, praises the simple folk or vox populi, the humble and folky ways, and not genuine democratic participation; instead, all the symbols of liberalistic enlightenment are under attack. ${ }^{50}$ By perpetuating the device of a truly democratic "mouthpiece of the people", the agitator also plays on the resentment of uneducated people against the educated (anti-intellectualism). Intellectuals represent rationality and critical consciousness and a lack of appreciation for 'traditional values - in opposition to what the agitator preaches. Moreover, he aims at popular consent by incorporating common sense arguments and popular resentments against "big business monopolies", or other socially common personifications of the anonymous causes of financial loss, such as the socially acceptable lament on "the banker". ${ }^{51}$ This is combined with a pseudo-democratic affirmation of the "little men" and the "ordinary people", the members of the "middle class", who are allegedly a victim of big business, corruption, and the "establishment". Thus he tries to don the mantle of populism.

(2) The character of the authoritarian agitator himself is ambiguous, for it needs to fulfil different functions: he is allegedly a 'man of the people' while being equipped with superior qualities that put him above all other humans. He depicts himself as one of the plain folk, "who thinks, lives, and feels like them. In agitation this suggestion of proximity and intimacy takes the place of identification of interests." ${ }^{\circ 2}$ He portrays himself as a "great little

\footnotetext{
48 Ibid.

49 Ibid, p.143.

50 See ibid, p.120f.

51 See ibid, p.52.

52 Ibid, p.129.
} 
man" who is simultaneously only a messenger. ${ }^{53}$ By seemingly talking "man to man" to his listeners and sharing their troubles, the agitator dispels the fear they may have that he is talking above their heads or against their institutionalized way of life. ${ }^{54}$ At the same time, he insinuates that he is a strong, bullet-proof, tough superhuman saviour to be adored, that he is intellectually and morally superior. He also supports his authority by pretending to have some superior, inside knowledge. The self-portrait of the agitator is, hence, constituted by a mixture of closeness and distance: one must be able to identify with the leader as an ordinary man, as one who is 'one of us' and who affirms 'what we are'. At the same time, he needs to offer satisfaction to the longing for a powerful superhuman whose orders one luckily obeys, in order to justify his unbound authority. The agitator can be imagined as powerful father-figure and attractive authority figure, surpassing the real father. Even more so, he presents a kind of an "elder brother", or, in Adornos phrasing, a tremendously enlarged projection of the weak ego. As Douglas Kellner puts it, "the follower is able to identify himself with the leader through identification with an idealized version of him or herself." ${ }^{, 55}$ By encouraging frivolous devaluations of out-groups or even sadistic fantasies and jokes, the agitator (unlike most other political leaders), Lowenthal claims, does not primarily or necessarily appear in the role of the restraining or moralizing father, but rather as the elder brother who leads a "rebellious" juvenile gang. ${ }^{56}$ In this context, he creates an image of a "persecuted innocence", a victim of (liberal) media and the "establishment" from which he and "we, the people" allegedly suffer, while he simultaneously keeps the 'courage' of the ordinary man against these hostile forces. The agitator himself does not display any weakness but consequence and strength. Thus the agitator is able to call for victimhood and punishment; he intends to satisfy "masochistic" and "sadistic" desires in the audience, and provides a feeling of security and protection to the

\footnotetext{
${ }^{3}$ See also Adorno, “The Psychological Technique of Martin Luther Thomas' Radio Addresses,” p.28.

${ }^{54}$ See Lowenthal, Prophets of Deceit, p.130.

${ }_{5}$ Douglas Kellner, Critical Theory, Marxism and Modernity (Baltimore: The Johns Hopkins University Press, 1989), p.119.

56 See p.127.
} 
weak subject. He furthers "the tendency to dispose of the individual by incorporating him into a collectivity, where he may feel 'sheltered' but where he has no say at all."57 Anti-democratic agitators express what the audience feels and thinks but is unable to express. The self-portrait of the agitator, Lowenthal suggests, is "thus a culmination of all the other themes, which prepare the audience for the spectacle of the great little man acting as leader. [...] He drives [the listeners] into a moral void in which their inner voice of conscience is replaced by an externalized conscience: the agitator himself. [...] He comforts the sufferers of malaise, takes the responsibility of history and becomes the exterior replacement of their disintegrated individuality." 58 However, as much as the agitator praises the "little men", "we, the people", the in-group, and their collective or national identity, he also establishes the inferiority of his prospective followers. In so doing, the agitator claims superior knowledge which, he implies, he has obtained by virtue of his special abilities. ${ }^{59}$ Through this humiliation, the demagogue appeals to masochistic dispositions among his listeners while "he transforms this very humiliation into something to be proud of, a mark of the new elite he will eventually elevate. ${ }^{60}$

(3) The authoritarian agitator in democracies pretends to be genuinely democratic but profoundly contradicts ideals of democracy, equality, and justice; he tends to explicitly reject the idea of universalism and individualism, and he emphasizes the primacy of ethnic or national collective entities over individual and democratic rights. He promotes the political construction of homogenizing narratives, and most social problems are read as a conflict between the in-group and the out-groups. But the distrust and fear of the stranger, the devaluation of the "others", seems to be the base of the agitator's nationalism, Lowenthal argues. ${ }^{61}$ However, to the disappointed, disoriented and authoritarian listeners, the affirmation

\footnotetext{
57 Adorno, “The Psychological Technique of Martin Luther Thomas' Radio Addresses," p.37.

${ }^{58}$ Lowenthal, Prophets of Deceit, p.145.

${ }^{59}$ See ibid, p.30.

60 Ibid, p.32.

61 See ibid, p.108.
} 
of national exclusiveness may mean the assurance that their (collective) identity will be preserved. Their sense of alienation and weakness may thereby be relieved, and compensated for by a sense of belonging to something, no matter how vague. ${ }^{62}$ Such collective narcissist gratifications provided by the collective self-image, social cohesion and exclusive group identification are further enhanced by the authoritarian power that the agitator presents. Tolerance, to the contrary, is portrayed as a cultural luxury preached by those "in power". Presumably the agitator often reframes issues and meanings: For instance, minority rights are turned into a matter of privilege, and "democracy" is transformed from a system that guarantees rights into one that merely affirms the privileged status of a homogenous or the "silent majority". ${ }^{63}$

(4) Although the authoritarian demagogue prefers radical solutions, his movement and goals are diffuse. While he only vaguely refers to iniquities in the political and social structures, he offers emotional gratifications. The authoritarian political program employs simple, especially personifying answers to the complexities of the modern world. The agitator does not offer substantial political programs, but constructs a binary "Either-Or world" that insinuates simple but radical solutions to complicated issues. ${ }^{64}$ Any concrete political ideas play but a minor role compared with the psychological stimuli applied to the audience. ${ }^{65}$ Some of the points of largely inconsistent right-wing authoritarian platforms, Lowenthal evaluates, are just "restatements of the stereotypical images of the enemy [...]; others are examples of shadowboxing; and still others are merely glittering generalities." ${ }^{\prime 66}$ Even more nebulous than his goals is his definition of the means by which he tends to achieve power. ${ }^{67}$ Accordingly, the agitator primarily offers emotional and psychological gratifications. The promise of those agitators, who portray themselves as the "constructive forces", refers to little

\footnotetext{
62 See ibid, p.108.

${ }^{63}$ See ibid, p.40.

${ }^{64}$ See ibid, p.104.

${ }^{65}$ See Lowenthal, Prophets of Deceit, see also Theodor W. Adorno, “Anti-Semitism and Fascist Propaganda,” p. 397.

${ }^{66}$ Lowenthal, Prophets of Deceit, p.102.

${ }^{67}$ See ibid, p.110.
} 
more than aggression and destruction itself. He stirs up emotions and fears which he amplifies, as he also primarily appeals to emotions. ${ }^{68}$ The movement is presented as a value per se, because it implies exclusion/oppression of the weak and exhibition of one's own power. ${ }^{69}$ In a way, Lowenthal argues, agitation partly functions as a gratification in itself. The primary function of the agitator's words, thus, is to release emotional reactions of gratification or frustration. He does so by playing upon prejudices and resentments which rationalize destructive fantasies. No resentment is "too small for the agitator's attention."70 All which can result for the follower is an inner exacerbation of his resentments, Lowenthal claims: "If the agitator cannot promise his adherents a greater share of the good things in life, he can suggest that the good life consists in something else, the gratification of repressed impulses; and if they are obedient to him they will be offered the luxurious sinners as sacrificial prey." ${ }^{\prime 1}$ The promise of sadistic gratification is relayed through linguistic stimuli. ${ }^{72} \mathrm{He}$ might also promote a collective enthusiasm that allows for a regressive loosening of self-control and a legitimized temporary loss of superego functions, as Freud had claimed in Mass Psychology and Ego Analysis.

(5) According to Lowenthal, it is obvious that the agitator wants to exploit existing discontent by targeting specific groups as responsible for society's problems. The agitator spends his energy to exaggerate and intensify the irrational elements in original complaints about the present situation. His way of addressing problems and discontent is by the recurring method of personification. When the agitator raises the question of the cause of social problems, his answer, as Löwenthal notes, invariably indicates a "who," rather than a "what." (Löwenthal, 1987: 21, emphasis in original). Every social phenomenon is reified, and every anonymous, complex social process or structure is personalized and ethnicized — and thus also simplified. Foremost, the agitator

\footnotetext{
${ }^{68}$ See also Frank Decker, Parteien unter Druck, p.51ff.

${ }^{69}$ See Theodor W. Adorno, "The Psychological Technique...," p.42.

${ }^{70}$ Lowenthal, Prophets of Deceit, p.18.

${ }^{71}$ Ibid, p.38.

${ }^{72}$ See ibid, p.125.
} 
finds "numerous vituperative and indignant references to enemies."73 Authoritarian agitation is essentially personalized propaganda. Its main features are ethnocentrism, xenophobia, and in particular anti-Semitic conspiracy myths. Authoritarian-nationalist agitation is consistently opposed to immigration and views foreigner as dangerous elements. Appealing once again to and emotions rather than policy arguments, political demagoguery can satisfy demands for collective narcissism and the longing for superiority by denigrating or demonizing others. Personification is consistently paired with dehumanization of the alleged "enemies of the people." "In portraying the enemy as ruthless," Löwenthal adds, "the agitator prepares the ground for neutralizing whatever predispositions for sympathy for the underdog his audience of underdogs may feel" (Löwenthal, 1987: 82). In addition to, most prominently, "the Jews" (or coded terms hinting at them) as the force of all presumed evil in the world, foreigners and refugees are charged with the image of the enemy. Löwenthal argues that for "the agitator, the refugee is the most fearsome version of the foreigner. The very weakness, the very plight of the refugees is an argument against them. . . The refugee becomes identified with the parasite who seeks dupes to do his dirty work."74 Refugees, Lowenthal observes, are frequently identified with the ancient figure of the outcast, an exile who does not deserve a better fate. ${ }^{75}$ The refugee's homelessness, Lowenthal suggests, also becomes the psychological equivalent of the audience's repressed instincts." "76 Playing with projective fantasies of the "helpless", "ruthless" and "eternal" enemies, the agitator gives his listeners legitimacy and permission to indulge in anticipatory fantasies in which they violently discharge those emotions ascribed to the alleged enemies. ${ }^{77}$ By his references to rape, incest, perversion, and plunder, the agitator evokes sadistic fantasies, Lowenthal argues, "that add a connotation of promise to the

\footnotetext{
73 Ibid, p. 21.

${ }^{74}$ Ibid, p.59.

75 See ibid, p.60.

76 Ibid, p.60.

77 See ibid, p.18.
} 
warning: his followers may vaguely hope that when the deluge comes they, too, maybe allowed to perform the acts that are attributed to the enemy." 78

(6) In forms of authoritarian agitation, hence, stereotypical attributions and projections generally play a crucial role, and they are frequently reiterated. They function as a 'legitimate' outlet for strong aggressive impulses harboured by authoritarian social demand. The promotion and reinforcement of social resentments is maybe the most central theme of radical right-wing agitation, which tends to contrast the in-group with a hostile world full of enemies. The pleasure of excluding and discriminating bolsters narcissistic aggrandizement through identification with the group a "delusion-like security” (Adorno et al, 1950: 619). When the agitator offers "a sense of belonging, "Löwenthal explains,

...his words find response only because men today feel homeless and need a new belief in the possibility of social harmony and well-being. And when he calls upon them to depend on him, he capitalizes on both their revolt against the restraints of civilization and their longing for some new symbol of authority. That which they utter under their breaths, the sub rosa thoughts that they are hardly ready to acknowledge to themselves become the themes flaunted in agitation. What the agitator does, then, is to activate the most primitive and immediate, the most inchoate and dispersed reactions of his followers to the general trends of contemporary society (Löwenthal, 1987: 151).

The partially subtle, often open discourse strategy to devalue or even dehumanize the perceived "enemies", as Lowenthal points out, seems to be a particularly appropriate "vehicle for projection by the masses of their unconscious realization that they are nothing, in many instances, but a mere mass. In violently eradicating the hated vermin, the sadomasochistic person tries symbolically to separate himself from the crowd and confirm his individuality."79 Furthermore, by simultaneously identifying the victim of persecution (the image of a "helpless" enemy) with the dangerous persecutor (the image of a "ruthless" enemy), the agitator sanctions and rationalizes an act of cowardice and impotence and makes it appear as an act of courage and wisdom. ${ }^{80}$ This fantastic fusion of ruthlessness and helplessness

\footnotetext{
78 Ibid, p.44.

${ }^{79}$ Ibid, p.67.

80 Ibid, p.69.
} 
continues to be most strongly and effectively represented by the anti-Semitic image of Jews as the quintessential essential other, although often in coded forms. ${ }^{81}$ The image of Jews is highly ambivalent and serves contradictory functions: Jews appear as envied and hated, advanced and backward-oriented, weak and powerful, as persecuted persecutors, in opposition to the agitator as a "persecuted innocence". Repudiations of antisemitism, even direct assertion of pro-Jewish feelings. ${ }^{82}$ In sum, they are the stereotypical embodiment of all aspects of modern life, of greed, intellect, power, money, individualism. Consequently, they are constructed as the embodiment of the threat of apocalyptic "decomposition", which signifies the permanent socio-cultural transformation processes in modern capitalism. Conspiracy theories, which might find their expression in anti-Semitism, go along with this mode of perception and political mobilization. As the agitator employs stereotypical projections that serve reified psychological needs and authoritarian desires. These projections provide personifying explanations for an increasingly complex social world, conspiracy theory and paranoic overtones seem to be essential ingredients. In nurturing the idea of a conspiracy directed against the in-group, the agitator plays upon and enlarges the tendency among the listeners "who suffer from a sense of failure to ascribe their misfortunes to secret enemy machinations." On a political scale he "stirs his audience to reactions similar to those of paranoia on an individual scale, and his primary means of doing this is by indefinitely extending the concept of conspiracy." ${ }^{, 83}$ To satisfy the audience's carving for an overall explanation of its sufferings, conspiracy myths provide easy-to-grasp responses personifying the complexities of the modern globalized world. The agitator thereby tends to present dissatisfaction, fear and wishes through "a fantastic and extraordinary image, which is the enlargement of the audience's own projections". The image of himself is, as we have seen, also blown out of proportion.

\footnotetext{
81 Ibid, p.73.

82 See ibid, p.78

83 Ibid, p.33.
} 
(7) Lowenthal also repeatedly finds apocalyptic scenarios that invoke the prediction of a total disaster. This further relieves the individual of responsibility for struggling with his problems, as an apocalypse is viewed as inevitable, and this serves as another stimulus to the listener's authoritarian aggressions and destructive instinctual urges, to which the can give gratifying play. Freed from the inhibitions of conscience, it is not difficult for the agitator, says Lowenthal, to "take a further step of projecting disaster onto the imaginary enemy."

(8) Authoritarian agitation contains hardly a manifest discursive logic; it is determined by endless repetition, ritualistic devices, a partially a religious language, andespecially under conditions of institutional democracies-innuendo. The characteristic "lure of innuendo," Adorno had previously pointed out, "grows with its vagueness". It allows for an "unchecked play of imagination" and invites all sorts of speculation as well as conspiracy myths. And it serves various political-psychological functions. It is (a) a way to promote resentments and conspiracy myths while (b) still somewhat adapting to democratic conventions, which today are rapidly eroding in the age of social media but may still impose certain limits on political discourse or even lead to legal prosecution in some national contexts. It has (c) another community-building effect: by working with allusions, the listeners are viewed as an in-group. Because the audience knows what the agitator means, this deepens the unconscious complicity between him and the listeners. ${ }^{85}$ Thus concord of feeling and opinion between agitator and listener is established, confirming a basic collective identity. To listen to innuendo and to rely on deliberatively vague statements requires a certain readiness to believe and to join into the community. ${ }^{86}$

In essence, authoritarian populists' repetitive ideologemes and tropes appeal to suppressed emotions, sentiments, and resentmentsand they function as a type of

\footnotetext{
${ }^{84}$ Ibid, p.46.

85 See ibid, p.14.

${ }^{86}$ Lowenthal, Prophets of Deceit, p.144.
} 
"psychoanalysis in reverse"-rendering facts and reasonable policies irrelevant but encouraging societal, civilizational transgressions in the name of civilization's ,restoration'.

\section{Towards a Critical Theory of Authoritarian Populism in Light of Lowenthal's Work}

My brief reconstruction of some key analytical elements of Lowenthal's work on authoritarianism indicates that there are historically recurring patterns in authoritarian political agitation and their underlying socio-psychological mechanisms.

In addition, my analysis shows Lowenthal's socio-theoretical understanding of enduring societal structures that have shaped persistent patterns of, what Samir Gandesha and I have called, "political modernity." 87 By that we mean general trends of for mass politics and ideologies as well as technocratic rule that are the product of conditions, aspirations contradictions which have emerged in the modern age yet which are not a matter of the past but remain all too present - including the capitalist economization and reification of most aspects of social, political, and public life, or the tendency to form powerful rackets and the enjoyment of ideologically driven mass rallies longing for authoritarian collective submission and civil transgressions.

The contemporary perspective points especially to what Lowenthal and Adorno conceived as the "rebellious" type, who is ready for an authoritarian revolt or anti-liberal, anti-democratic counter-revolution. His revolt is directed against social value change as well as established authorities and orders perceived as weak--with the goal to replace such authority while "rehabilitating" certain conformist ideals and repressive, exclusionary group norms. The type or syndrome of authoritarian rebellion may be of particular importance as a tool to describe and understand the current populist crowd(s). In this case, authoritarian aggression is discharged in a markedly free and unsublimated form, provided that it is

\footnotetext{
${ }^{87}$ Lars Rensmann and Samir Gandesha, „Understanding Political Modernity: Rereading Arendt and Adorno in Comparative Perspective," in Lars Rensmann/Samir Gandesha, eds., Arendt and Adorno: Political and Philosophical Investigations (Stanford: Stanford University Press, 2012), pp.1-27.
} 
legitimized by new, apparently stronger authority figures who take the place of the old authorities. The theory of authoritarian rebellion describes an authoritarian admixture of conformism and revolt: a rebellion is carried out against societal authority figures sometimes against the State itself. The rebellion might come about because the established authority is suddenly unable to radiate the strength that was once both admired and feared, the power to create order and to clamp down.

Lowenthal saw the authoritarian potential on the rise on a global scale, affecting and potentially undermining even the oldest democracies. In Lowenthal's earlier contributions to the Institute's research project on Anti-Semitism among American Labor, the susceptibility of authoritarian dispositions, stereotypes and anti-Semitism among the working class in industrial societies had been demonstrated. The potential and the dynamics of social and political authoritarianism eventually observed among American workers in the 1940s, then, had shown that this form of "reified consciousness" and authoritarian disposition and tendency to attribute the "social malaise" to a Jewish conspiracy, and the reemergence of authoritarian politics, were a problem also affecting consolidated liberal democracies, and of potentially global scope.

Reconstructing Lowenthal's work in view of partially changed socio-political conditions, his work may serve as a critical resource for theoretically framing the authoritarian appeal of current populist agitators, from Trump to Salvini. Lowenthal's work can, in addition to others, inspire and help reconstruct a critical framework for theorizing/thinking through the explosive, rebellious authoritarian political-psychological dynamics and politico-cultural expressions of today and their socio-economic as well as political conditions. Despite its shortcomings, such theorizing may complement current explanations of the populist surge in an age of a profound digital transformation of the public sphere, and under conditions of twenty-first century capitalist democracies. 
Three insights and directions are of particular interest for theorizing contemporary populism. First, there is the dimension of political psychology proper. Lowenthal's framing of "demagogues within democracy" as father-brother types, who engender collective narcisstic gratifications by alluding to unchecked power and strength yet also to the brotherhood and shared language of the allegedly cheated 'common man', is insightful for our understanding of the appeal of authoritarian populists the world over.

Effective contemporary and past authoritarian agitators often combine a strongman's father-like "toughness," pretending to aggressively provide authoritarian communal protection and restoring ethno-national privilege, with a jargon of authenticity and a common man/brother brand, designed to establish strong emotional links with one's followers. Instead of proposing feasible policy solutions, Lowenthal's agitators present themselves as true representatives of the demos and "people like us" who are simultaneously superior saviors forcefully rescuing the nation from alleged crisis and disaster. Stylizing themselves as audacious taboo breakers, the American demagogues analyzed by the Frankfurt School employ the language of common men to which they claim to belong, yet portray themselves as vastly superior saviors of the nation who will save the country from "crisis and disaster." Authoritarian populism, in this lens, in part draws its appeal from offers (through the agitator and/or through the idealized collective) of narcissistic compensation and gratification for weakened subjects overburdened with modern civilization. It provides delusions of grandiosity in which one can partake through the leader's greatness or the greatness of the allegedly ,authentic“ collective that is portrayed as both superior and under imminent threat. And it allows to legitimately act out—-thinly rationalized—-societal transgressions in the cultural and political sphere in the name of the leader, the collective, the people, or some other politicized higher moral good in contrast to existing legal and social norms.

Lowenthal critically theorizes a set of repetitive statements and ideological repertoires appealing to appeal to suppressed emotions, sentiments, and resentments and functioning, in 
essence, as a "psychoanalysis in reverse," obscuring, legitimizing and amplifying unfiltered aggressions rather than helping to process them. Lowenthal's analysis is grounded in an advanced critical social theory of objectification in modern society which weakens individual and public autonomy as forces potentially resisting authoritarianism. Lowenthal seeks to explain the reified idolization of the ingroup of "real citizens" which is paired with the lure of post-factual conspiracy myths that reduce social complexity by projectively blaming "others" or "enemies of the people" as illegitimately privileged actors who are to be stripped of their power. Wild projections of fears and hopes, resonding to the social desire to 'let loose' and transgress boundaries, replaces all reasonable reflection about better policies. Therey by the how, the method, the procedure, the psychosocial gratifications delivered in a revolt against „the elite“ and „the others“ outweighs the what, the content of specific policies. Lowenthal's theory of authoritarianism helps understand the important role of authoritarian populists' transgressions of established social, civil and political norms. The way populist agitators justify rebellions against government authorities portrayed as "weak" and the suspension of civil rights in the name of freedom and "true democracy" hereby points to underlying paradoxes and constitutive contradictions of modern post-liberal capitalist democracies conceptually unfolded in Critical Theory. Lowenthal offers a heuristic conceptual framework to decode the recurring underlying political-psychological dynamics which constitute often standardized interactions between political agitators and their imagined communities. For Lowenthal, the agitator hardly offers any specific political objectives or rational structural criticism, but promises nebulous, diffuse prospects for a better, if not glorious and harmonious future without indicating concrete measures to achieve it; he promises rather psychological gratifications based upon moral rationalizations for loosened self-control, blown-up collective self-images providing feelings of power, and projections that function as wish-fulfilment of hidden or prohibited authoritarian fantasies and unconscious desires. Lowenthal notes that the agitator seeks political integration by enhancing various unconscious identification processes, 
amalgamating agitator, follower, and the collective idealized collective entity/region/nation or community of insiders designed to participate in the imagined strength of the self-declared 'heroic leader'.

Finally, right-wing authoritarian populism, following Lowenthal, exploits and reinforces social and psychological fears. It utilizes social disintegration and socio-cultural transformation processes to which it reacts. This surfing on a highly emotionalized language spoiling fears related to immigration, cultural change, and socioeconomic depravation is constitutive for right-wing populist agitation techniques and contents as it apparently was among the rightist agitators in the middle of the $20^{\text {th }}$ century. The agitator, who suggests a permanent crisis and an emergency situation for the imagined, homogeneous community he re-signifies and "defends", thus insinuates that he and his movement are the "last solution" to all problems that burden the individual and society today. Logical contradictions and factual errors are irrelevant in that context, argues Lowenthal; what matters is the fantasy of redemption, and general the psychological appeal and the functions it fulfils.

The second direction Lowenthal points to involves the relationship between authoritarian populism and the political economy. In light of Lowenthal's work, the authoritarian backlash twenty-first century capitalist democracies experience the world overthough to varying degrees in different politico-cultural contexts - may point to an underlying, lingering authoritarianism in modern societies that has never gone away since the days of totalitarianism and fascism. Such authoritarianism, which provides fertile ground for authoritarian populism, is in Lowenthal's diagnosis shaped by often unacknowledged or rationalized forms of irrational social domination. Yet more specifically, Lowenthal suggests, it may also point to profound problems originating in monopolistic trends of unregulated modern capitalism and the enormous inequalities of resources and power it produces (this Lowenthal and the Frankfurt School observed already in the first half of the twentieth century). 
Authoritarian agitators and organized forms of political authoritarianism, in Lowenthal's view, utilize and reinforce problems and contradictions of liberal-democratic capitalist society itself: its failed promises to equality and freedom; its lack of democratic inclusion and its insufficient participation/representation; its radically monopolistic trends under conditions of unrestricted market liberalization and welfare regress; its partially repressive, assimilationist egalitarianism and conformism following capitalist demands and forcing latent cultural homogenization; its oppressive structures, practical social Darwinism and its practices of social exclusion, atomization and marginalization, and related contradictions of modern capitalism. The agitator's themes are "distorted versions of genuine problems. [...] When he takes advantage of the anxiety and fears of his listeners, he is playing on very real anxieties and fears; there is something to be anxious and fearful about. When he offers them a sense of belonging, no matter how counterfeit it is, and a sense of participation in a worthy cause, his words find response only because men today feel homeless and need a new belief in the possibility of social harmony and well-being." 88

The origins of the current authoritarian revolt, while not any unmediated expression of class positions, class conflicts or the „social question“ (as noted, many authoritarians are among the wealthy and well-off), may thus also be deeply social (and here I cite Adorno and Horkheimer, who wrote this in collaboration with Lowenthal): „The purpose of human rights (and liberal democracy, one may add), was to promise happiness even where power was lacking. Because the cheated masses are dimly aware that this promise, being universal, remains a lie as long as classes exist, it arouses their anger; they feel themselves scorned. ${ }^{689}$ Right-wing political propaganda, then, to some extent exposes and exploits the liberal belief that all men are equal and are the masters of their own individual destiny, while capitalism, and especially so contemporary capitalism in its post-liberal condition, displays this belief as a lie. By means of a neo-liberal regime of deregulation, an unrestricted, economically post-

\footnotetext{
${ }^{88}$ Lowenthal, Prophets of Deceit, p.151.

89 Adorno \& Horkheimer, Dialectic of Enlightenment, p.141.
} 
liberal capital concentration and post-industrial monopolies have emerged that are similar to monopolies of the post-liberal period of the industrial age. In this process, a new multibillionaire capitalist aristocracy, based primarily on global investment, real estate and social media corporations and inherited wealth, permanently exposes the contradictions and limits of liberal claims to freedom and democratic claims to the self-rule of formally equal citizens. Political authoritarianism, in light of Lowenthal's Critical Theory, thereby exploits social fears and inequalities, and insinuates to bridge the actually existing democratic gaps and social disintegration visible in liberal society. By claiming to re-build a community and by pretending to articulate the unified political 'will of the people', the authoritarian agitator could appear as the true democrat, even though he might have nothing to offer but his own authoritarianism and the ultimate destruction of constitutional democracy alongside the rights and freedoms it still grants.

Third and finally, a significant path to be developed for a critical theory of populism after Lowenthal to which I can only allude here is social theory models proper, which links insights into the political psychology and political economy of authoritarianism with the Frankfurt School theory of social reificiation and objectification in a productive, reconstructive way, in other words: to actualize a critical understanding of the current authoritarian revolt's distinct conditions in the context of the modern dialectics of objectification, fetishization, and social domination.

For Lowenthal and the Frankfurt School, it is the dominant objectifying identity logic, with its blind affect against non-identity and social difference that helps engender such regressive collective rebellions based on pathic or false projection and social or group paranoia. Such paranoic delusions about the world — detached from reality, experience, and better arguments — are inherently destructive and self-destructive. Against the backdrop of these arguments, it is worth theorizing in how far today's apocalyptic populist delusions are linked to post-industrial, postliberal capitalist society's patterns of social domination: a bolstered social darwinism, which shows little mercy and operates crudely in objectified economic terms of win or lose, success or failure, 
and with which the post-modern authoritarians strongly identify-even if they are themselves on the losing end; as well as the flourishing fetishization of identity, directed against individuality, pluralistic freedom and diversity, and universal emancipation.

The discussion about the social origins of this demand points to the social fragmentations and reifications that modern societies produce; to underlying, structural social conditions and the decentered nature of resentments, which can serve particular needs and functions: the affirmation of fractured identities; the projection of wishes, fantasies and fears; and the desire to 'let loose' and transgress boundaries in the context of delusions within societies in which the distribution of wealth and resources has become extremely unequal and the respective social exclusions increasingly brutal on a global scale. While the democratization of resentment has been strongly advanced by social media, Critical Theory shows us that authoritarian politics driven from below are not entirely new phenomena; neither are the enormous gaps in fragmented, profoundly unequal societies that contribute to liberal democracy's present legitimacy crisis. Applying the Frankfurt School to contemporary populist phenomena in Europe and the US may also help illuminate the deeper origins and scope of this challenge. 